\title{
Electrochemical Study of Interaction of Bacteria and Clay
}

\section{Koffi OE ${ }^{1,2}$, Bile BE ${ }^{2}$, Bengourram $\mathrm{J}^{3}$, Tankiouine $\mathrm{S}^{4}$, Latrache $\mathrm{H}^{4}$ and Chtaini $\mathrm{A}^{{ }^{*}}$}

${ }^{1}$ Equipe Electrochemistry and Molecular Inorganic Materials, University Sultan Moulay Slimane, Faculty of Science and Technology, Morocco

'Laboratory of Physical Chemistry, University of Felix Houphouet Boigny Cocody, Côte d' Ivoire, Morocco

${ }^{3}$ Laboratoire Industrial Engineering, Faculty of Science and Technology of Beni Mellal, Morocco

${ }^{4}$ Laboratoire of Bioprocess and Biointerfaces, Faculty of Science and Technology of Beni Mellal, Morocco

\begin{abstract}
The electrochemical behavior of bacteria, such Staphylococcus aureus, at clay modified carbon paste electrode is reported. The influence of variables such as the accumulation time, optical density (OD) was tested by square wave voltammetry (SWV), cyclic voltammetry (CV) and electrochemical impedance spectroscopy (EIS). The interaction of bacteria and metal surface is discussed. A novel clay electrode (Arg-E) was fabricated for directly determination of bacteria in water or whole blood samples. The optical density of bacteria (OD) was determined and its evolution with the current density was plotted.
\end{abstract}

Keywords: Bacteria; Modified electrode; Square wave voltammetry; Cyclic voltammetry

\section{Introduction}

Bacterial contamination of food and water is one of major problems of public health in developed and developing countries. Conventional microbial detection methods rely on observing the physical growth of bacterial cells or monitoring the release of their metabolites. To isolate and identify the target organisms from the complicated food ecosystems, an enrichment procedure is commonly needed in microbial analysis of food samples. This is often followed by a sub culturing step by plating the enrichment mixture on a selective or differential solid medium and incubating the samples in selective temperatures or atmospheres [1]. Biochemical tests are conducted to ultimately identify the microorganisms. Various biochemical tests are available to measure specific microbial metabolic activities, such as the catalase reaction, $\beta$ - hemolysis, and $\mathrm{H}_{2} \mathrm{~S}$ release from triple sugar iron agar [2]. The conventional method for detecting a bacterial pathogen makes use of the antibodies against it. This method has some drawbacks: Its sensitivity is insufficient; bacteria must be purified from biological samples; and the process takes many hours. Rapid and sensitive methods of microorganism's detection and identification are of great importance. Recently, analytical biosensors provide a promising alternative for direct pathogenic microorganism's determination in areas such as clinical diagnostics, food analysis, bioprocess and environmental monitoring [3-12]. A biosensor is an analytical device that integrates a biological element on a solid-state surface which enables a reversible bio specific interaction with the analytes, and a signal transducer [13]

Electrochemical methods offer selectivity and sensitivity due to the selective detection of electroactive species among the complex samples. Chemically modified electrodes show certain merits like easy surface renewal, low cost, low residual current and ease of fabrication.

The objective of this study was to develop a sensitive and a cost effective method for rapid detection of bacteria, such Staphylococcus aureus

\section{Experimental}

\section{Reagent}

All chemicals were of analytical grade and have been used as received without any further purification. All solutions were prepared in double distilled water. The commercial graphite powder was supplied from France. The clay samples employed in the research were taken from the Natural Resources of Cameroon, more precisely from the town of Garoua, in the region of North Cameroon. The treated kaolin [13] has the following chemical composition: $\mathrm{SiO}_{2}$ (48.01\%), $\mathrm{Al}_{2} \mathrm{O}_{3}$ (27.41\%), $\mathrm{Fe}_{2} \mathrm{O}_{3}$ (7.34\%), $\mathrm{MnO}(0.12 \%), \mathrm{CaO}(0.06 \%), \mathrm{MgO}(0.31 \%)$, $\mathrm{K}_{2} \mathrm{O}(0.41 \%), \mathrm{Na}_{2} \mathrm{O}(0.02 \%), \mathrm{S}(0.03 \%)$ and several metals in the range of ppm.

The bacterial strain used in this study was Staphylococcus aureus ATCC 25923. The strain was cultured in Luria Bertani broth at $37^{\circ} \mathrm{C}$ for $24 \mathrm{~h}$ after culture; the cells were harvested by centrifugation for 15 $\mathrm{min}$ at $8400 \mathrm{xg}$ and were washed twice with and resuspended in $\mathrm{KNO}_{3}$ solution with ionic strength $0.1 \mathrm{M}$. The physicochemical properties of this strain were measured by contact angle measurements.

Provisions were made for oxygen removal by bubbling the solution with azotes gas for about $5 \mathrm{~min}$ then the solution was blanketed with azote gas while the experiment was in progress. For reproducible results, a fresh solution was made for each experiment.

\section{Instrumental}

Voltammetric experiments were performed using a voltalab potentiostat (model PGSTAT100, EcoChemie B.V., Utrecht, The Netherlands) driven by the general purpose electrochemical systems data processing software (voltalab master 4 software) run under

*Corresponding author: Chtaini A, Equipe Electrochemistry and Molecular Inorganic Materials, University Sultan Moulay Slimane, Faculty of Science and Technology, Morocco, Tel: +212 661-118521; E-mail: a.chtaini@usms.ma

Received December 31, 2015; Accepted February 02, 2016; Published February 09, 2016

Citation: Koffi OE, Bile BE, Bengourram J, Tankiouine S, Latrache H, et al. (2016) Electrochemical Study of Interaction of Bacteria and Clay. J Microb Biochem Technol 8: 060-064. doi: 10.4172/1948-5948.1000263

Copyright: ๑ $2016 \mathrm{Koffi}$ OE, et al. This is an open-access article distributed under the terms of the Creative Commons Attribution License, which permits unrestricted use, distribution, and reproduction in any medium, provided the original author and source are credited. 
windows 2007 . The three electrode system consisted of a chemically modified carbon paste electrode as the working electrode a saturated calomel electrode (SCE) serving as reference electrode, and platinum as an auxiliary electrode.

\section{Electrodes}

Modified electrodes were prepared by mixing a clay powder with paraffin oil used as a binder. The body of the working electrode for voltammetric experiments was a PTFE cylinder that was tightly packed with clay paste. The geometric area of this electrode was $0.1256 \mathrm{~cm}^{2}$. Electrical contact was made at the back by means of a bare carbon.

\section{Results and Discussion}

Figure 1 shows the effect of the addition of bacteria to electrolyte support solution $(0.1 \mathrm{M} \mathrm{NaCl})$, using cyclic voltammetry $(\mathrm{CV})$. It is observed that bacteria produce two anodic peaks, the first one at 0.4 $\mathrm{V}$ and the second one at about $1 \mathrm{~V}$. Further, square wave voltammetry (SWV) was also employed to study the effect of the presence of bacteria in supporting electrolyte. Bacteria show a well-defined peak at Arg-E (Figure 2). The prepared electrode has easily detected the presence of bacteria in the electrolytic solution.

An impedance spectroscopy study was performed in order to confirm the results obtained by the cyclic voltammetry tests. Figures 3 show the impedance diagram recorded for clay paste electrode, in case of the absence (curve a) and in the case of the presence of bacteria (curve b), in supporting electrolyte. EIS is right which means that there is a diffusion at the surface of the clay, for the presence of bacteria the impedance curve observed decrease of the charge-transfer resistance means also that the prepared electrode becomes more conductive, which can be explained by the presence of staphylococcus at the surface.

The diameter of the half loop corresponds to the resistance of the electrons transfer step. We find that this resistance decreases in the presence of bacteria in the media (Table 1). The capacity of the double layer decreased, corresponding to the film formation at the metal / solution interface.

The effect of the electrochemical treatment on the formation of the biofilm, on the electrode surface, was evaluated by the representation of the absorbance values before and after treatment (Table 2). The most prominent effect observed were the mass bacteria decreasing in the electrolytic solution, thereby confirming the formation of a biofilm on the surface of the electrode.

This phenomenon has been investigated by the polarization curves of the prepared electrode, in electrolytic medium containing or not bacteria. The electrochemical parameters determined from the polarization curves are given in Table 3 . The polarization current density of clay paste electrode increased when bacteria are added to the electrolytic solution. The value of the anode slope lowered remarkably when bacteria are added to the electrolytic solution, while the anode slope value has not changed. This means that the process, effectively, takes place at the electrode surface.

The electrode response was tested for OD solutions in the range from 0.020 to 0.250 . Figure 4 shows some of typical square-wave voltammetry curves recorded at clay paste electrode after being in contact with different bacteria concentrations. A calibration graph

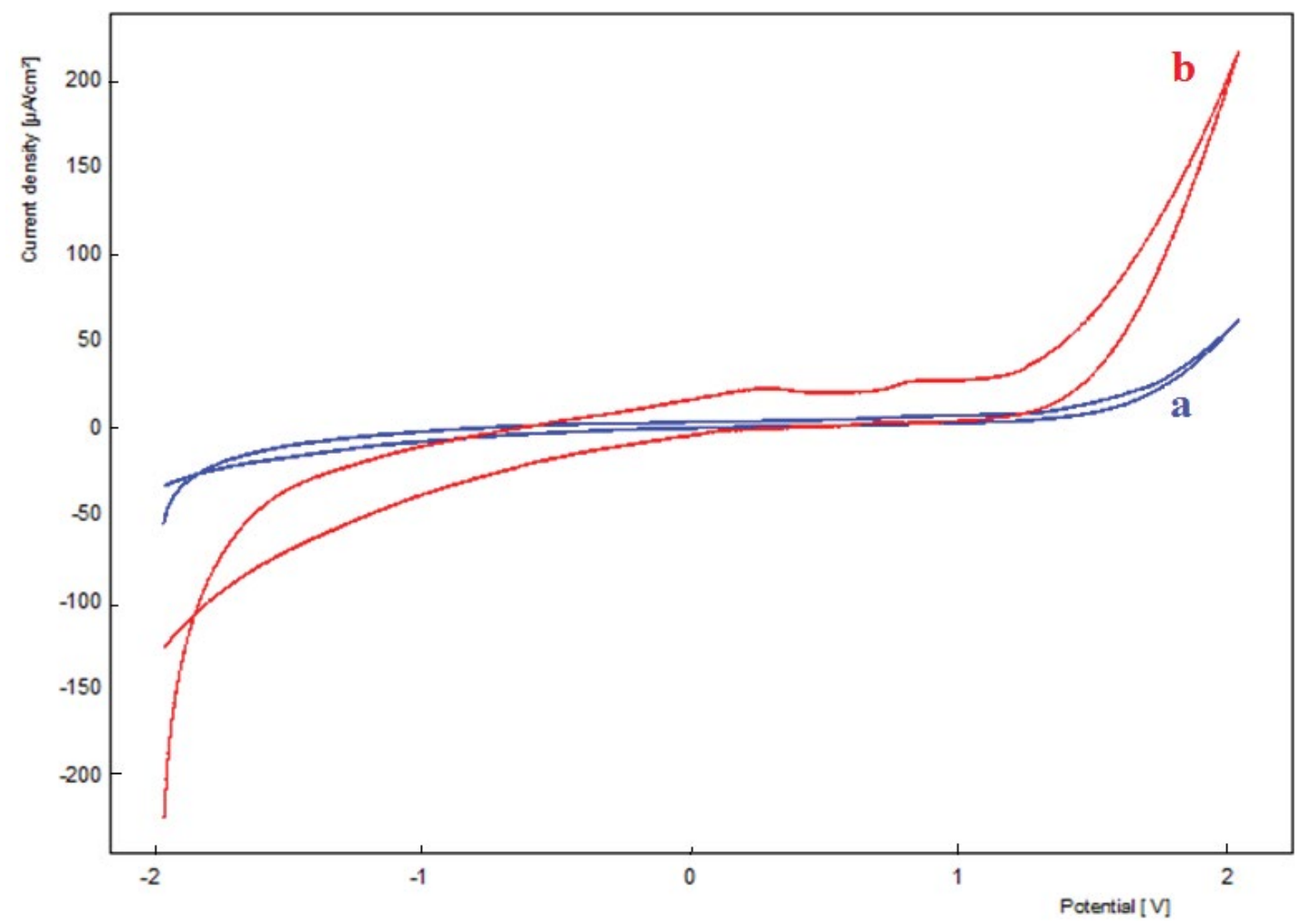

Figure 1: Cyclic voltammograms recorded for Clay paste electrode in, a- $0.1 \mathrm{M} \mathrm{NaCl}$ solution b- $0.1 \mathrm{M} \mathrm{NaCl}$ containing bacteria, at $100 \mathrm{mV} / \mathrm{s}$. 
Citation: Koffi OE, Bile BE, Bengourram J, Tankiouine S, Latrache H, et al. (2016) Electrochemical Study of Interaction of Bacteria and Clay. J Microb Biochem Technol 8: 060-064. doi: 10.4172/1948-5948.1000263

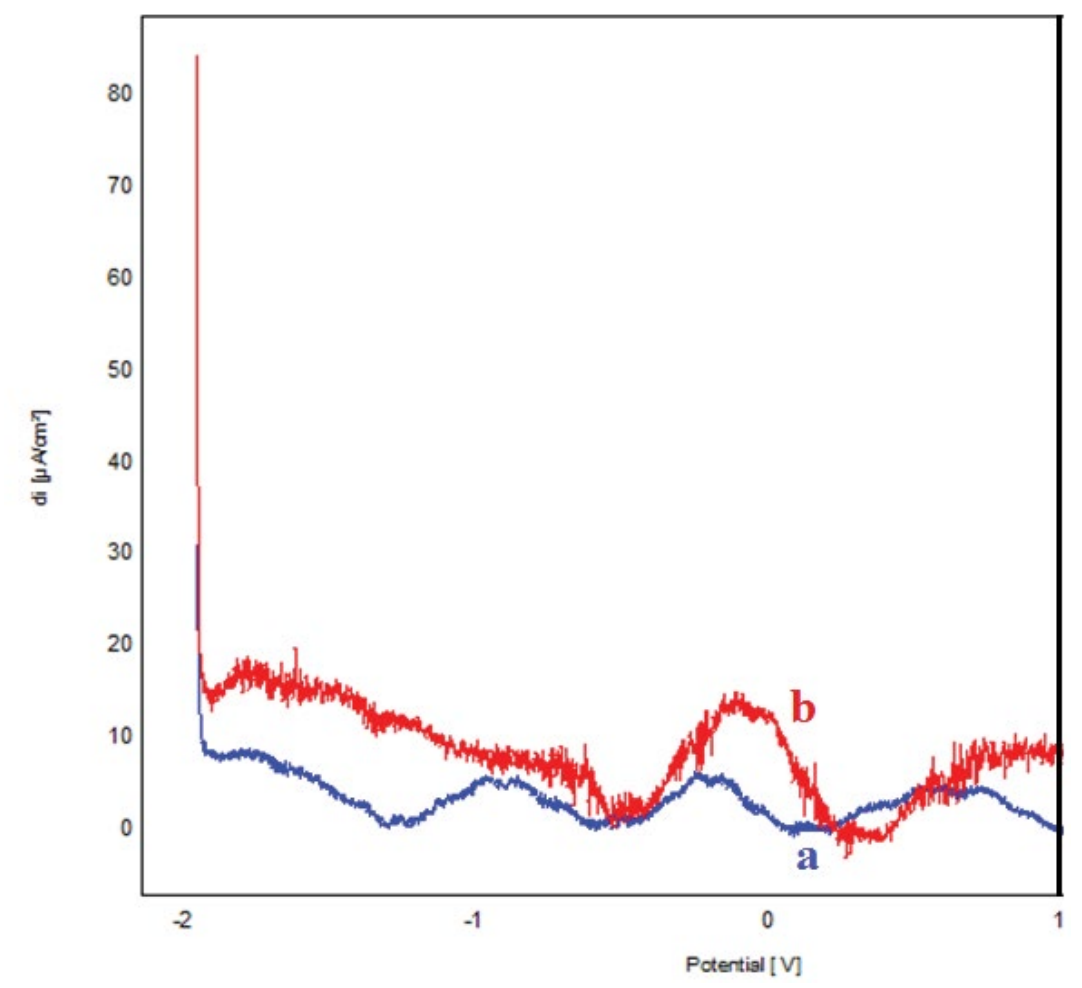

Figure 2: SWV's recorded for Clay paste electrode in, a- $0.1 \mathrm{M} \mathrm{NaCl}$ solution b- $0.1 \mathrm{M} \mathrm{NaCl}$ containing bacteria, at $100 \mathrm{mV} / \mathrm{s}$.

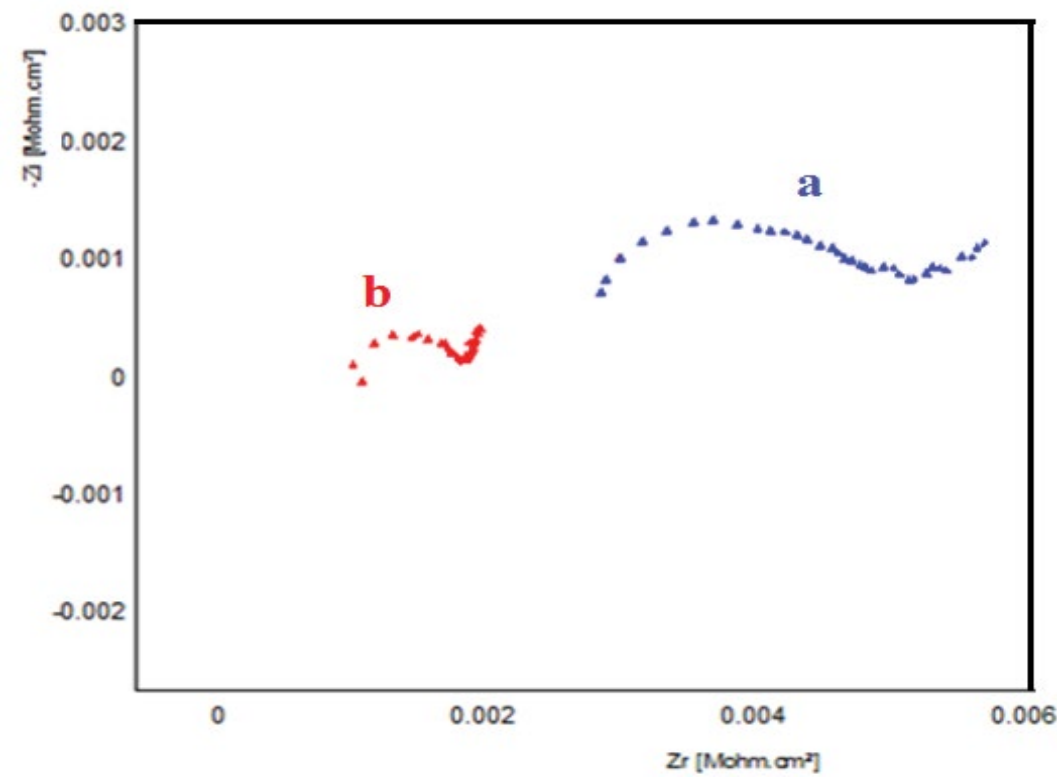

Figure 3: Electrochemical Impedance spectroscopy recorder at clay paste electrode in: $0.1 \mathrm{M} \mathrm{NaCl}$ solution, b- $0.1 \mathrm{M} \mathrm{NaCl}$ solution containing bacteria.

was then constructed from the observed peak currents. The SW Voltammetric response was linearly dependent on the OD of solution (Figure 5).

In order to obtain an analytical curve and electrochemical parameters for the developed sensor, we carried out square wave voltammograms for the presence of bacteria in supporting electrolyte, at different concentrations of bacteria. The decrease in optical density (OD) of the solution is an indication of loss of the bacteria in medium. 
Citation: Koffi OE, Bile BE, Bengourram J, Tankiouine S, Latrache H, et al. (2016) Electrochemical Study of Interaction of Bacteria and Clay. J Microb Biochem Technol 8: 060-064. doi: 10.4172/1948-5948.1000263

\begin{tabular}{|c|c|c|c|c|}
\hline $\begin{array}{c}\text { Supporting } \\
\text { Solution }\end{array}$ & $\begin{array}{c}\text { Diameters } \\
\left(\text { kohm. } \text { cm }^{2}\right)\end{array}$ & R1 (kohm.cm²) & R2 (kohm.cm²) & $\mathrm{C}\left(\mathrm{nF} / \mathrm{cm}^{2}\right)$ \\
\hline $0.1 \mathrm{M} \mathrm{NaCl}$ & 2,789 & 2,379 & 2.782 & 1.281 \\
\hline
\end{tabular}

Table 1: Electrochemical parameters.

\begin{tabular}{|c|c|c|}
\hline & $\begin{array}{c}\text { Before electrochemical } \\
\text { treatment }\end{array}$ & $\begin{array}{c}\text { After electrochemical } \\
\text { treatment }\end{array}$ \\
\hline Optical Density (OD) & 0.741 & 0.484 \\
\hline
\end{tabular}

Table 2: Optical density (OD).

\begin{tabular}{|l|c|c|}
\hline \multicolumn{1}{|c|}{ Electrolytic solution } & $\mathbf{0 . 1} \mathbf{~ M ~ N a C l}$ & $\mathbf{0 . 1} \mathbf{~ M ~ N a C l}+$ bacteria \\
\hline $\mathbf{E}(\mathbf{i}=\mathbf{0}) \mathbf{~} \mathbf{m V}$ & $-1046,3$ & $-801,5$ \\
\hline $\mathbf{R p}\left(\mathbf{k o h m} . \mathbf{c m}^{2}\right)$ & 115,39 & 39,49 \\
\hline $\mathbf{I}\left(\boldsymbol{\mu A} / \mathbf{c m}^{2}\right)$ & 0,4498 & 288,2 \\
\hline $\mathbf{B a}(\mathbf{m V})$ & 412,8 & 288,2 \\
\hline $\mathbf{B c}(\mathbf{m V})$ & $-227,4$ & $-287,2$ \\
\hline
\end{tabular}

Table 3: Electrochemical parameters.

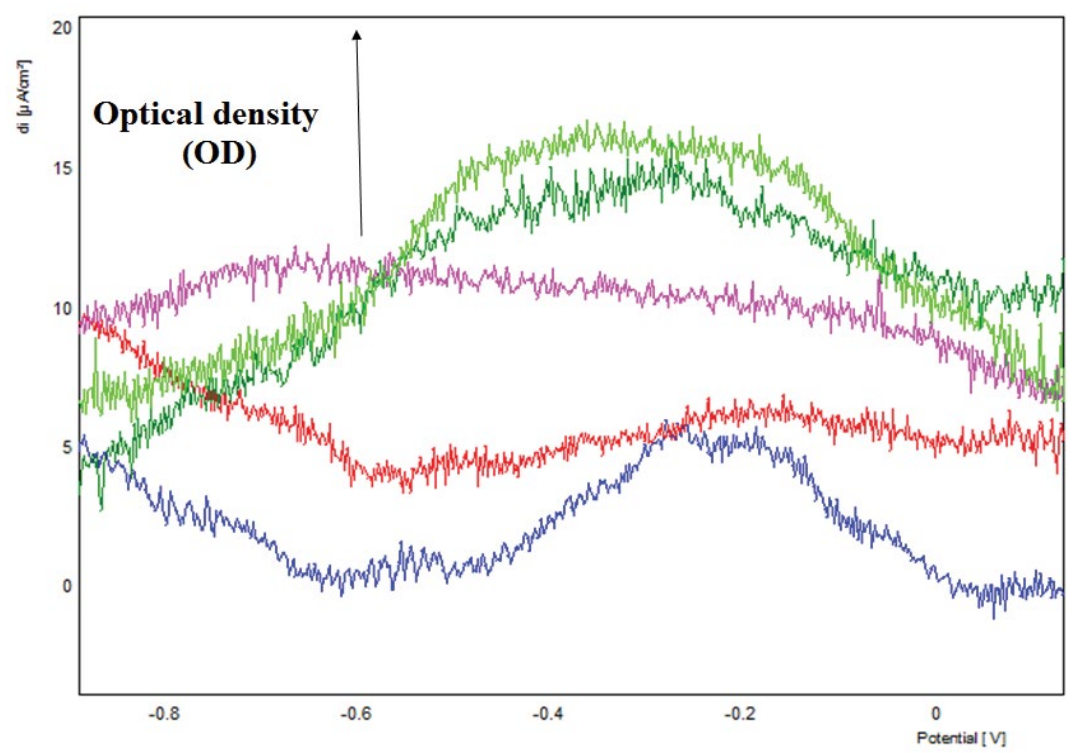

Figure 4: SWV's recorded for Clay paste electrode in $0.1 \mathrm{M} \mathrm{NaCl}$ solution. Evolution of the current density peak with OD.

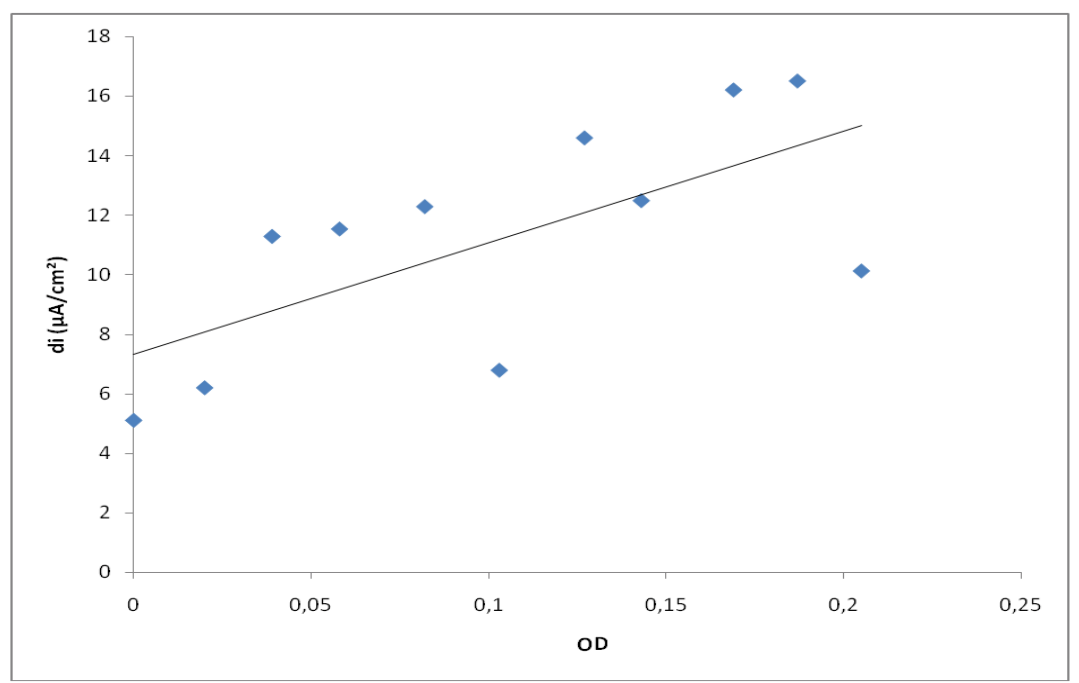

Figure 5: Plot of peaks area versus optical density.

\begin{tabular}{|c|c|c|c|c|c|c|c|}
\hline OD & 0,020 & 0,039 & 0,082 & 0,103 & 0,169 & 0,187 & 0,205 \\
\hline$E(i=0) m V$ & $-798,3$ & $-915,9$ & $-891,5$ & $-820,7$ & $-940,2$ & $-965,9$ & $-921,7$ \\
\hline Rp (kohm.cm²) & 25,24 & 23,18 & 22,16 & 26,38 & 29,02 & 35,56 & 33,27 \\
\hline $\mathrm{I}_{\mathrm{p}}\left(\boldsymbol{\mu} \mathrm{A} \cdot \mathrm{cm}^{2}\right)$ & 2,554 & 2,881 & 2,768 & 2,187 & 2,281 & 1,8275 & 1,2276 \\
\hline $\mathrm{Ba}(\mathrm{mV})$ & 426,8 & 497,1 & 361,4 & 364,8 & 433,9 & 469,0 & 258,9 \\
\hline $\mathrm{Bc}(\mathrm{mV})$ & $-360,4$ & $-363,7$ & $-396,2$ & $-347,8$ & $-400,2$ & $-372,7$ & $-257,1$ \\
\hline
\end{tabular}

Table 4: OD evolution with electrochemical parameters. 
Citation: Koffi OE, Bile BE, Bengourram J, Tankiouine S, Latrache H, et al. (2016) Electrochemical Study of Interaction of Bacteria and Clay. J Microb Biochem Technol 8: 060-064. doi: 10.4172/1948-5948.1000263

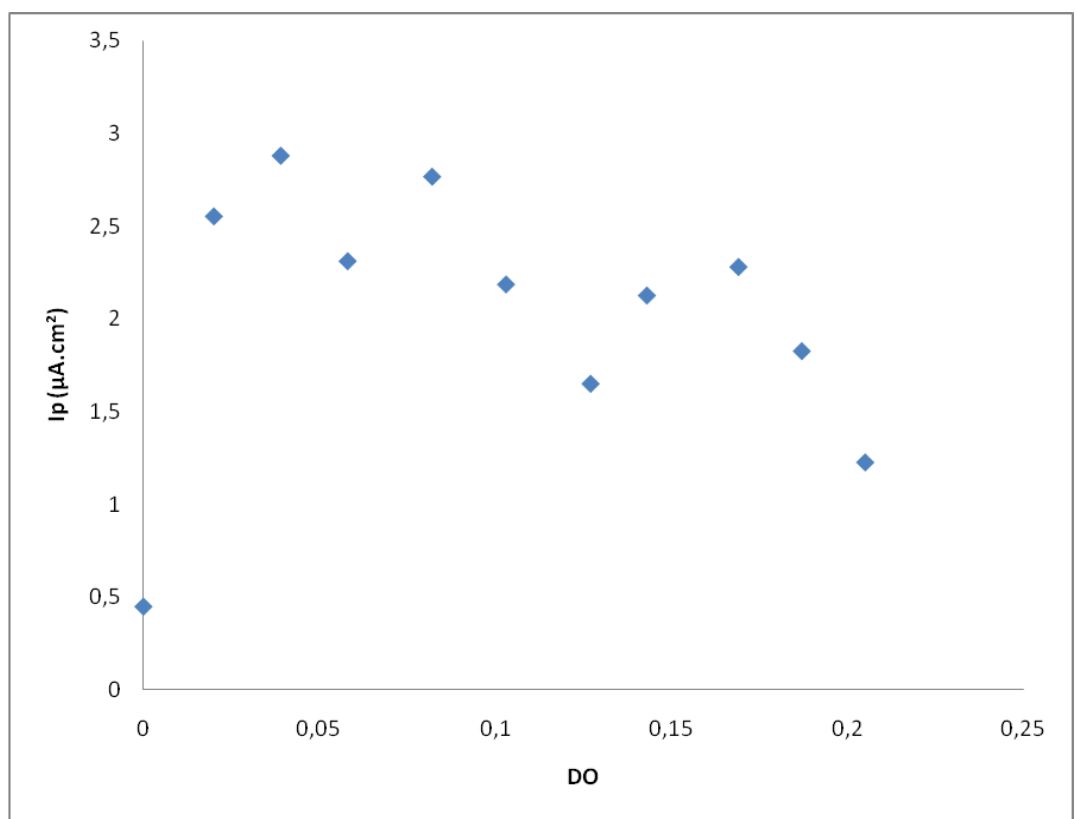

Figure 6: Polarization current density dependence of the optical density of solution.

This decrease in the OD of the solution is accompanied by the growth of the polarization current density of the electrode surface, leaving suggest that bacteria have formed a biofilm on the surface of the clay (Table 4) and Figure 6.

\section{Conclusion}

In the present work, clay paste electrode was prepared and successfully applied to determinate bacteria in $0.1 \mathrm{M} \mathrm{NaCl}$ solution. Cyclic voltammetry has shown that the presence of bacteria in supporting solution gives two anodic peaks at clay paste electrode. The developed SWV method can be used for determination of quantitative values of bacteria OD. The developed method will also be useful for its application in water analysis.

\section{References}

1. Mossel DAA (1977) Microbiology of Foods. CRC Press, Cleveland.

2. Yousef AE, Carlstrom C (2003) Food Microbiology: a laboratory manual. Wiley \& Sons, New Jersey.

3. Iqbal SS, Mayo MW, Bruno JG, Bronk BV (2000) A review of molecular recognition technologies for detection of biological threat agents. Biosensors and Bioelectronics 15: 549-578.

4. Andreotti PE, Ludwig GV, Peruski AH, Tuite JJ, Morse SS, et al. (2003) Immunoassay of infectious agents. Biotechniques 35: 850-859.

5. Peruski AH, Peruski LF (2003) Immunological methods for detection and identification of infectious disease and biological warfare agents. Clinical and Diagnostic Laboratory Immunology 10: 506-513.

6. Nayak M, Kotian A, Marathe S, Chakravortty D (2009) Detection of microorganisms using biosensors-A smarter way towards detection techniques. Biosensors and Bioelectronics 25: 661-667.

7. Skládal P, Ková D (2013) Electrochemical immunosensors for detection of microorganisms. International Journal of Electrochemical Science 8: 16351649
8. D'Orazio P (2003) Biosensors in clinical chemistry. Clin Chim Acta 334: 41-69.

9. Cruz HJ, Rosa CC, Oliva AG (2002) Immunosensors for diagnostic applications. Parasitol Res 88: S4-7.

10. Luppa PB, Sokoll LJ, Chan DW (2001) Immunosensors--principles and applications to clinical chemistry. Clin Chim Acta 314: 1-26.

11. Lazcka O, Del Campo FJ, Muñoz FX (2007) Pathogen detection: a perspective of traditional methods and biosensors. Biosens Bioelectron 22: 1205-1217.

12. Deisingh AK, Thompson M (2004) Biosensors for the detection of bacteria. Can J Microbiol 50: 69-77.

13. Ouafy A, Chtaini H (2015) Electrochemical Detection of p-Chloroaniline at Clay Modified Carbon Paste Electrode: Application in Tap Water. J Drug Metab Toxicol 5: 6 . 